\title{
Breeding practices and preferred traits of indigenous chicken in Western Oromia region, Ethiopia
}

\author{
G. Fekede ${ }^{1 *}$ and Y. Tadesse ${ }^{2}$
}

${ }^{1}$ Oromia Agricultural Research Institute Bako Agricultural Research Center, P.O.Box.03, Bako; ${ }^{2}$ School of Animal and Range Sciences, Haramaya University, P.O.Box.138 Dire Dawa Ethiopia,

*Corrresponding Outher : Email- gutufekede@ gmail.com ; Mobile phone : +251-912866043

Journal of Livestock Science (ISSN online 2277-6214) 12: 85-94

Received on 27/11/20; Accepted on 25/1/2021, Published on 1/2/2021

doi. 10.33259/JLivestSci.2021.85-94

\begin{abstract}
The study was conducted in Bako Tibe and Dano districts of Western Oromia region, Ethiopia with the objectives to generate the relevant information regarding breeding practices, objectives, and farmers' trait preferences of local chickens under scavenging production systems. Data were collected using semi-structured formal questionnaires and focus group discussions. A total of 119 households (60 from Bako Tibe and 59 from Dano district), were randomly selected using a multi-stage sampling technique. The study revealed that egg consumption, chick sale, and meat consumption were the main purposes of keeping indigenous chicken in BakoTibe and Dano districts. The result indicates that the majority of the respondents $(87.43 \%)$ were practiced selection of hens and cocks for breeding purposes emphasizing the production of a high number of eggs, body size, brooding ability, leg length to select hens. Whereas body size, growth rate, leg length, comb shape in their order of importance to select breeding cocks. The selection of these traits indicates that egg and meat production was the major aims of the farmer to raises chickens in the study districts. Generally, chicken production is an important economic activity to improve the livelihood of smallholder households. Therefore the future research has been focused on the farmers' production objectives and trait preference of chickens to improve the productivity of indigenous chickens through the selection and crossbreeding of local chickens with exotic breeds in the semi-scavenging chicken production systems in the study area.
\end{abstract}

Keywords: livelihood; multi-stage sampling; production objectives; trait preference; indigenous chicken; Ethiopia 


\section{Introduction}

Chickens constitute about 90 percent of the poultry population and are, by far, the most important poultry species in all parts of the world (FAO, 2014). Indigenous breed is a general terminology to describe those birds kept in the extensive system, scavenging in the free-range, have noidentified description, multi-purpose and unimproved (Horst,1989) and they are reservoirs of genetic materials for genetic studies, improvement, preservation and conservation (Daikwo et al., 2011, Ekka et al, 2016). In Ethiopia, chicken production is an important and integral part of most households in rural, urban and peri-urban areas like other developing countries, enabling farmers to harvest the benefits of high-quality protein in the form of eggs and meat from only scavenging feed resources (Habte et al., 2017). Even though the total chicken population in Ethiopia is large in number and estimated at 59.495 million, the annual output is only 13,111 metric tonnes of meat and 54,395 metric tonnes of eggs (FAOSTAT, 2016). The average per capita chicken product consumption is less than $1 \mathrm{~kg}$, which is one of the lowest in the world (Boere et al., 2015; FAS,2017), indicating a huge gap between demand and supply of poultry products (meat and eggs) in the country.

The mean annual egg production potential of indigenous chicken has not exceeded 60 eggs/hen with an average egg weight of 40gm (FAO, 2019; Hunde et al., 2016; Adem and Teshome, 2016) and the average weight of hens and cocks were $1.14 \mathrm{~kg}$ and $1.45 \mathrm{~kg}$, respectively (Fisseha,2014) which indicates their low performances. However, the production potential of indigenous chicken is low in comparison to commercial chickens, they have added advantages of sustainable development due to adapting to harsh environments and recognized for their ability to survive and reproduce in these conditions (Fisseha et al., 2010; Wong et al., 2017). Indigenous chicken maintained under the traditional system contributed about $94.31 \%$ of the total national poultry products (eggs and meat) while the remaining $2.49 \%$ is obtained from an intensively kept exotic breed of chickens and $3.21 \%$ are obtained from hybrids in Ethiopia (CSA, 2016/2017).

Low performances of indigenous chickens have enforced the government to introduce exotic breeds from the temperate region to improve their performance through crossbreeding with exotic chicken strains, which has been unsuccessful for the past decades. These may be due to, dissemination of inappropriate technologies without an understanding of production environments under which indigenous chickens are kept and lack of information on breeding objectives and farmers' trait preferences (Nigussie et al., 2010).

Information on production environments, indigenous breeding practices, breeding objectives, and farmers' trait preferences require for designing, planning, and implementing agro-ecologically friendly and sustainable genetic improvement programs of indigenous chickens thus to ensure sustainable improvement, utilization, and conservation of indigenous chicken genetic resources and uplift their contributions on the livelihoods of small scale farmers. However, hitherto in the west Shoa zone of the Oromia region, very little effort has been made to identify breeding objectives and farmer's chicken breeding practices of indigenous chicken ecotype before genetic improvement is made through cross and breeding selection. Therefore the study was designed to generate the relevant information regarding farmers breeding practices, objectives, and preferred traits of indigenous chicken under scavenging production systems in the Bako Tibe and Dano districts of west Shoa zone of the Oromia region.

\section{Materials and Methods}

\section{Description of the study areas}

The study was conducted in Bako Tibe and Dano districts of Western oromia region, Ethiopia (Fig.1). The selected districts were categorized into three agro-ecological zones namely; lowland, midland and highlands based on traditional form of classification. The areas are situated between $8^{0} 37^{\prime} 0^{\prime}$ to $9^{0} 17^{\prime} 40^{\prime \prime} \mathrm{N}$ longitudes and $36^{\circ} 53^{\prime} 20^{\prime \prime}$ to $37^{\circ} 34^{\prime} 0^{\prime \prime}$ E latitudes. They have an altitude ranges from 1400 to $2800 \mathrm{~m}$ a.s.l. and recieves mean annual temperature varies from $13.3^{\circ} \mathrm{C}-30^{\circ} \mathrm{C}$ and mean annual rain fall ranges from $900-1400 \mathrm{~mm}$, which were mainly characterized by mixed crop-livestock farming system (Bako Tibe and Dano Districts Agricultural and Natural Resource Office, 2017). 


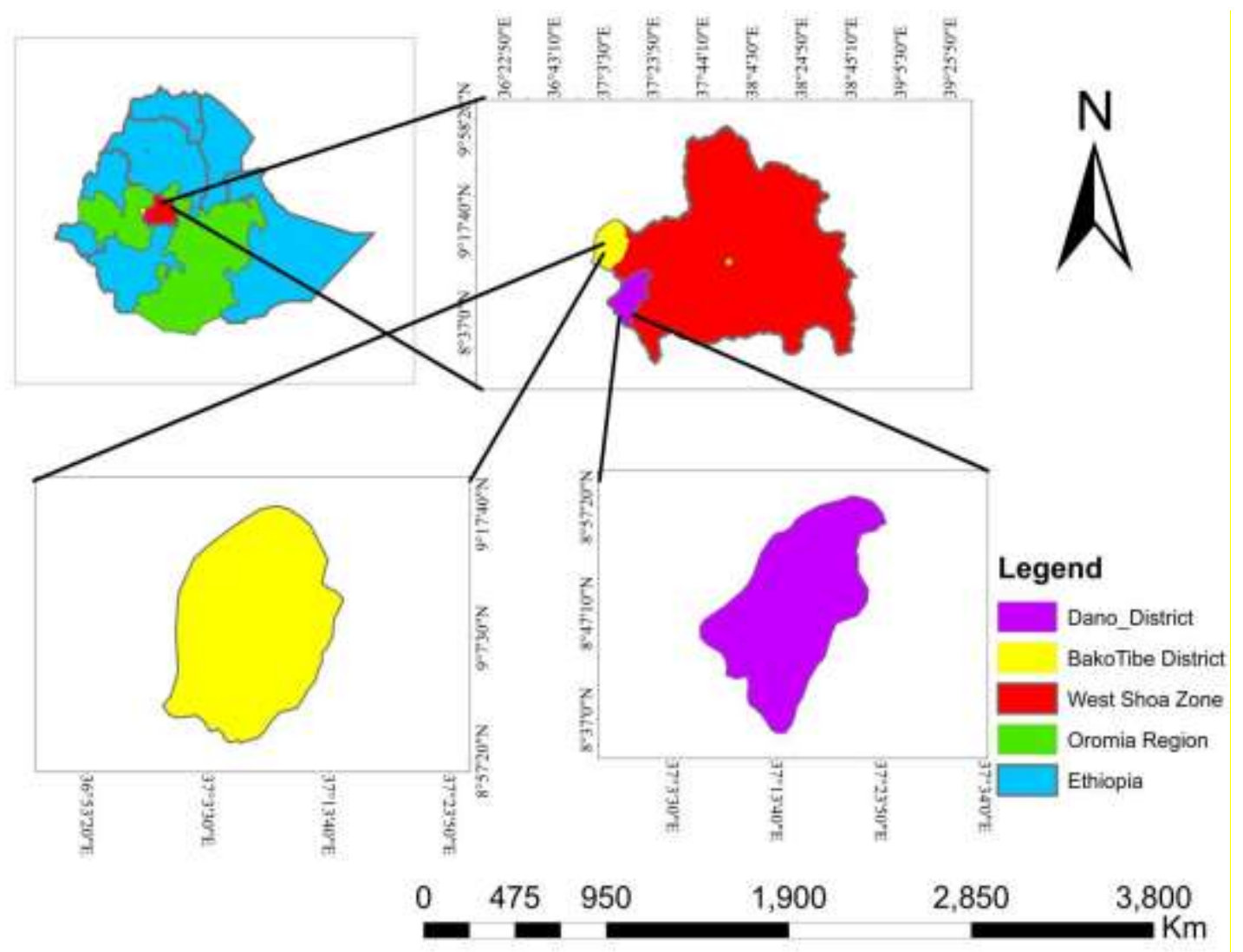

Fig.1:Map of the study area.

\section{Methods of Data Collection}

Multi-stage sampling procedures (purposive and random) were applied for the selection of districts, villages, and chicken keeper households in each district. A rapid field survey was made before the actual survey work to gather information on a chicken production system, indigenous knowledge husbandry, and breeding practices of chickens in the study area. The two districts were purposively selected based on; a large number of chickens, a high number of smallholders rearing chicken, the percentage contribution of chicken to household income/nutrition, and percentage market share gained by smallholders, availability of feed resources. Based on the above criteria three kebele from each district and six kebele in two districts were randomly selected. Random sampling procedures were applied to select a total of 119 households, 60 households in Bako Tibe and 59 households from the Dano district were considered by giving equal chance for all households.

In this study, qualitative and quantitative research approaches were employed. Qualitative data were obtained through observations made by enumerators and researchers and group discussions held with farmers, whereas quantitative data were obtained by interviews. The questionnaire was administered and focal group discussions were held in both districts. The information included in the questionnaire were socio-economic characteristics of the farmers, production and reproduction traits, selection criteria which was administered to the randomly selected household heads by a team of enumerators recruited and trained for the purpose under close supervision by the researcher. Focal group discussions held in each of the selected kebele by including youngsters, women, village leaders, and socially respected individuals who have better knowledge on the present and past social and economic status of the area.

\section{Statistical data analysis}

The collected household data was organized and analyzed with the help of Statistical Package for the Social Sciences (SPSS) version 20 (SPSS, 2011). Descriptive Statistical was employed to describe various collected data. A T-test was employed to detect statistical differences among two districts. The model statement used to investigate the effects of district difference on chicken flock size per household and various performance-related parameters of existing chicken production practices were: 
$\mathrm{Yij}=\mu+\mathrm{Ai}+\varepsilon \mathrm{ij}$

Where, Yij= the value of the respective variables

$\mu=$ overall mean of the respective variables,

$\mathrm{Ai}=$ Effect of the ith district ( $\mathrm{i}=2$, BakoTibe and Dano) on the respective variables

$\varepsilon i j=$ residual error term

The ranking of variables was done by using the rank index formula as described by Kosgey (2004). Index = sum of [3 $\mathrm{x}$ rank $1+2 \mathrm{x}$ rank $2+1 \mathrm{x}$ rank 3] divided by sum of [3x rank1+2 x rank $2+1 \mathrm{x}$ rank 3] for purpose of keeping chickens of households in the area. For trait preference of hens and cocks, Index $=\operatorname{sum}$ of $[5 \mathrm{x}$ rank $1+4 \mathrm{x}$ $\operatorname{rank} 2+3 \mathrm{x}$ rank $3+2 \mathrm{x}$ rank $4+1 \mathrm{x}$ rank5] divided by the sum of [5 $\mathrm{x}$ rank $1+4 \mathrm{x}$ rank $2+3 \mathrm{x}$ rank $3+4 \mathrm{x}$ rank $2+5 \mathrm{x}$ rank1] trait preferred for hen and cocks by households.

\section{Results and Discussion}

\section{Household characteristics and respondents profile}

The socio-economic characteristics of the respondents are presented in Error! Reference source not found. The average age of respondents was 40.91 \pm 1.01 years, which implies that the respondents were in an active productive age group. The current result is in line with Fisseha et al. (2010) and Emebet et al. (2013) who reported that the average age of respondents in Bure, Dawo, and Sedan Sodo districts was 40.90 years. The present results indicated that about $81.50 \%$ of the interviewed farmers were male-headed households and a small proportion of female household heads indicated in the study area. Even though more percent of interviewed households were male-headed, women were decided on the use and benefit obtained from chickens. In agreement to present results, Getachew et al.(2015) reported the interviewed farmers in the Bench Maji Zone were $72.78 \%$ and $27.22 \%$ of males and females, respectively.

There was a significant $(\mathrm{P}<0.05)$ difference in household family size between the two districts and higher in Dano than in the Bako Tibe district. The overall mean family size per household was 6.33 persons. This shows that the productive labor necessary for care, marketing, and management of chickens was dominant in the family. The current result was higher than the national average of 4.6 persons reported by CSA (2012) and similar to the findings of Fisseha et al. (2010) and Dereje et al. (2015) who reported 6.2 and 6.7 persons per household for Bure

district and western Oromia, respectively. In contrast, the result was lower than the finding of Dereje and kefalegn (2016) who reported 7.05 \pm 2.59 in Bako Tibe and 7.17 \pm 3.21 in Gobu Sayo districts.

In the present study, the average age of chicken keeping experience of the respondents is 11.43 years, which implies the farmers had more experience to rear chickens. This may lead to higher technical efficiency in poultry production, including efficient use of inputs in the study area. The average landholding per household in the current study was $1.87 \pm 0.15$ ha with a range of $0-10$ ha. The current result is higher than the report of Fisseha et al. (2010), who reported the average landholding per household was 1.23 ha in Northwest Amhara. Large land unit in the current result indicates that farmers have the opportunity to allocate his land for poultry feed production in addition to produce other crops which has a positive influence on poultry production.

The result indicates that almost half of the respondents attended primary school while about one-third of the respondents were illiterate. The current result was higher than the finding of Getachew et al.(2015) who reported $26.67 \%$ of the respondents in the Bench Maji zone were illiterates. However, in agreement with the current results Eskindir et al. (2013) reported $36.84 \%$ of respondents were illiterate in the Horro district. The presence of one-third of illiterate from the overall respondents in the study area might negatively influence the perception of village chicken technology transfer in the communities.

The current study also indicates that households in the study districts derived their livelihoods from many different sources. However, crop farming was the major source $(54 \%)$ of livelihoods of the households followed by livestock keeping in the study area. This indicates that livestock production was important in the livelihood strategies of most households of the study districts and simple reliance on crop farming seems necessary but not sufficient to sustain the livelihood of the farming households without livestock production and also most of the sample households have mixed farming systems integrating crop production with livestock rearing. 
Fekede \& Tadesse, 2021/J. Livestock Sci. 12: 85-94

Table 1.Socio-economic status of the indigenous chicken owner in the study districts

\begin{tabular}{|l|l|l|l|l|l|}
\hline Farmers characteristics & Bako Tibe (\%) & Dano (\%) & Overall (\%) & \\
\hline \multirow{3}{*}{ Gender } & Male & 73.30 & 89.80 & 81.55 & \\
\cline { 2 - 6 } & Female & 26.70 & 10.20 & 18.45 & \\
\hline \multirow{3}{*}{$\begin{array}{c}\text { Educational } \\
\text { level }\end{array}$} & Illiterate & 41.70 & 28.81 & 35.26 & \\
\cline { 2 - 6 } & primary school (1-8) & 38.30 & 54.24 & 46.27 & \\
\cline { 2 - 6 } & Secondary school (9-12) & 20.00 & 16.95 & 18.48 & \\
\hline $\begin{array}{l}\text { Sources of } \\
\text { lively hood }\end{array}$ & Crop farming & 53.00 & 55.00 & 54.00 & \\
\cline { 2 - 6 } & Livestock keeping & 30.00 & 22.00 & 26.00 & \\
\cline { 2 - 6 } & Domestic work in their own home & 15.00 & 14.00 & 14.50 & \\
\cline { 2 - 6 } & Livestock and livestock product trading & 2.00 & 9.00 & 5.50 & \\
\hline \multicolumn{2}{|l|}{ Age(year)/(mean) } & Mean \pm SD & Mean \pm SD & Mean \pm SD & P-value \\
\hline Family size (No $) /(m e a n)$ & $39.97 \pm 10.96^{\mathrm{a}}$ & $41.86 \pm 11.14^{\mathrm{a}}$ & $40.91 \pm 11.05$ & 0.351 \\
\hline Male ( No ) & $5.83 \pm 2.156^{\mathrm{b}}$ & $6.83 \pm 2.086^{\mathrm{a}}$ & $6.33 \pm 2.12$ & 0.012 \\
\hline Female ( No ) & $3.12 \pm 1.730^{\mathrm{a}}$ & $3.63 \pm 1.46^{\mathrm{a}}$ & $3.37 \pm 0.16$ & 0.10 \\
\hline Experiences of Chicken Rearing (year) & $2.78 \pm 1.236^{\mathrm{a}}$ & $3.22 \pm 1.34^{\mathrm{a}}$ & $3.00 \pm 0.12$ & 0.067 \\
\hline Land holdings(ha)/mean & $11.80 \pm 7.73^{\mathrm{a}}$ & $11.85 \pm 7.24^{\mathrm{a}}$ & $11.83 \pm 7.49$ & 0.721 \\
\hline \multirow{2}{*}{ SD: } & $1.58 \pm 1.46^{\mathrm{a}}$ & $2.17 \pm 1.83^{\mathrm{a}}$ & $1.88 \pm 1.65$ & 0.058 \\
\hline
\end{tabular}

SD: standard deviation, same superscript indicates non-significant differences; different superscript indicates significant differences; (\%): Percent.

\section{Chicken flock compositions}

The average chickens flock size and structure and their composition per household are presented in Table 2. Village chicken production is an important activity in the study areas. However, there was a significant difference $(\mathrm{P}<0.05)$ between the two districts in terms of average holding per household of indigenous chickens, which were higher in BakoTibe than the Dano district. The variations in flock size were may be due to the way farmers manage their chickens were different in both districts. The result obtained in this study was in line with Wondu et al. (2013), who reported 10.44 chickens per household in Northern Gonder. However, the present finding was higher than the reports of Emebet et al. (2013) and Yadeta et al. (2019), who reported the average flock size per household was 4.85 and 8.42 in Southern Ethiopia and southwestern Ethiopia, respectively. The average males to female ratio are 1: 1.99 and 1:2.74 in Bako Tibe and Dano district respectively. The average males to female ratio are 1: 1.99 and 1:2.74 in Bako Tibe and Dano district respectively. The current results were lower than the report of Fisseha et al. (2010) who report the average male to female ration were 1:3.3 and 1:3.2 in Fogera and Bure districts respectively hence the recommended cock to hen ratio in modern light and heavy breeds are 1:10 and 1:8, respectively.

\section{Reproduction and egg production performance of indigenous chickens}

The reproductive and productive performance of indigenous chickens is presented in

Table 2.The overall mean age at sexual maturity of cocks and hens were $24.30 \pm 0.764$ and $26.15 \pm 1.01$ weeks, respectively. The present result was in line with the findings of Eskindir et al. (2013), who reported 6.51 months of the average age at sexual maturity of hens in the Horro districts, and Janvier et al. (2017) who reported the average ages at first mating and laying of local chickens were $6.24 \pm 0.14$ and $7.05 \pm 0.13$ months, respectively in Rwanda. Conversely, it was higher than the finding of Addisu et al. (2013), who reported the mean age of sexual maturity of females was $23.84 \pm 0.05$ weeks in the Fogera district.This indicates better management practice can be improved age at first mating of local female chickens.

The result shows the average number of egg/clutch/hen was $13.38 \pm 0.60$ and the average number of times hen hatches in a year was $3.58 \pm 0.15$ with an estimated average egg number of 47.90 per year in the study area. The current result of the average eggs/clutch/hen was comparable with Alem (2014) and Chencha and Hailemichael (2016) who reported 13.60 and 14.09 in central and southern zone of Tigray, respectively. However, lower than the finding of Fisseha et al.(2010) who reported 15.70 and 14.90 eggs/clutch with estimated total egg production/ birds/year of 60 and 55 eggs in Bure and Dale districts, respectively.

The average number of chicks hatched per brood and number of chicks surviving to adulthood in the study districts were $10.54 \pm 0.51$ and $7.95 \pm 0.58$, respectively. This shows that one-quarter of the chicken was lost at a time due to poor husbandry practices in the study area. The current findings were in line with Fisseha et al. (2010), who reported the average number of chicks survived from the average number of egg hatched (11 and 10.2) were 6.7 and 
7.6 in Bure and Fogera districts respectively. The different results on local poultry breeds show that good poultry husbandry practices could improve the percentage of survivability of hatched chicken and the income of the households.

Table 2. Flock structures, Productive and reproductive performance of indigenous chickens

\begin{tabular}{|l|c|c|c|c|}
\hline Variables & Bako Tibe & Dano & total mean & P-value \\
\hline Flock structures (Mean \pm SE) & & & & \\
\hline Cocks & $1.37 \pm 0.12^{\mathrm{a}}$ & $0.86 \mathrm{~b} \pm 0.13^{\mathrm{b}}$ & $1.12 \pm 0.16$ & 0.036 \\
\hline Hens & $2.72 \pm 0.33^{\mathrm{a}}$ & $2.36 \mathrm{a} \pm 0.19^{\mathrm{a}}$ & $2.54 \pm 0.26$ & 0.349 \\
\hline Cockerels & $1.48 \pm 0.356^{\mathrm{a}}$ & $0.20 \mathrm{~b} \pm 0.08^{\mathrm{b}}$ & $0.84 \pm 0.22$ & 0.001 \\
\hline Pullet & $1.40 \pm 0.27^{\mathrm{a}}$ & $0.46 \mathrm{~b} \pm 0.15^{\mathrm{b}}$ & $0.93 \pm 0.21$ & 0.003 \\
\hline Chicks & $7.12 \pm 0.88^{\mathrm{a}}$ & $2.46 \mathrm{~b} \pm 0.44^{\mathrm{b}}$ & $4.79 \pm 0.66$ & $<.0001$ \\
\hline Total & $14.08 \pm 1.57^{\mathrm{a}}$ & $6.34 \mathrm{~b} \pm 0.64^{\mathrm{b}}$ & $10.21 \pm 1.10$ & $<.0001$ \\
\hline Reproductive and productive performances(Mean $\pm \mathrm{SE})$ & \multicolumn{5}{|l|}{} \\
\hline Age of sexual maturity of hens (wks) & $26.56 \pm 0.62$ & $25.74 \pm 1.40$ & $26.15 \pm 1.01$ & 0.908 \\
\hline Age of sexual maturity of cocks (wks) & $23.22 \pm 0.65$ & $25.37 \pm 0.86$ & $24.30 \pm 0.76$ & 0.098 \\
\hline Average number of eggs /clutch & $13.28 \pm 0.73$ & $13.47 \pm 0.46$ & $13.38 \pm 0.60$ & 0.819 \\
\hline Number of times the hen hatches/year & $3.61 \pm 0.17$ & $3.54 \pm 0.12$ & $3.58 \pm 0.15$ & 0.428 \\
\hline Average number of eggs/ brood & $12.44 \pm 0.44$ & $12.58 \pm 0.44$ & $12.51 \pm 0.44$ & 0.829 \\
\hline Average number of chicks hatched/brood & $10.50 \pm 0.5$ & $10.58 \pm 0.52$ & $10.54 \pm 0.51$ & 0.914 \\
\hline Number of chicks/brood surviving to adulthood & $8.00 \pm 0.52$ & $7.89 \pm 0.644$ & $7.95 \pm 0.58$ & 0.900 \\
\hline
\end{tabular}

SE: standard error, the same superscript across the rows indicate non-significant differences, different superscript indicate significant differences.

\section{Purpose of keeping local chickens}

The purpose of keeping indigenous chicken is present in Table 3. The main production objectives of indigenous chickens in the study area have multiple roles. Egg consumption followed by egg and chick sale was the main purpose of keeping indigenous chickens in the study area. This indicates that the objective of indigenous chicken production was to improve the nutrition status and generate income sources of the households since they can be reared in situations with limited feed and housing resources. The current result was similar to Wondu et al. (2013) who reported village poultry kept for home consumption and income generation in the Northern Gondar zone. Correspondingly, Addisu et al. (2013) reported egg and meat were the major chicken products for home consumption and sales.

\section{Farmers' trait preferences of chickens}

The trait preferences of households for chickens in the study area were presented in Table 3. The current result indicates that the majority of the respondents in the study area were selected hens and cocks for breeding purposes. The respondents select and retain hens in the flock mainly because of high egg production followed by body size/weight, brooding ability, the growth rate in BakoTibe district whereas, body size/weight was ranked first followed by egg productivity, brooding ability, and growth rate in Dano district.

The selection of these traits indicates that egg and meat production was the major aims of the farmer to raises chickens in the study area. The current study was in line with Hailemichael et al. (2015) who reported the majority of farmers selected breeding hens based on egg production, brooding ability, large body size, plumage color, and comb type in the Southern zone of Tigray. The current study and various studies indicated that farmers were given more emphasis on egg production, brooding ability, growth, and hatchability to select and retain in the flock of local chickens.

Farmers in the study area were choice different traits to selected cock for breeding purposes. The preferred traits were body size/weight, growth rate, leg length in their order of importance in Bako Tibe, and body size, comb shape, and body/feather color were the major traits ranked in their order of importance in Dano district. Hence, considering these traits preferences of the community could be useful in the implementation of the breeding program in the study area. In consonance with current results Muchadeyi et al. (2009) reported body size was the first ranked trait among the criteria for choosing chicken breeding stock in Zimbabwe.

\section{Breeding practices}

Breeding practices were presented in Table 4. The current result indicates that the majority of the respondents $(87.43 \%)$ in the study area were selected chickens for breeding purposes. The result was comparable with Fisseha et al. (2010) and Dereje et al. (2015) who reported the majority of farmers in the Bure district of the Amhara region and farmers in Western Oromia, respectively had the tradition of selecting cocks and hens. The result also indicates that $93.50 \%$ of the farmers in the study area were used an uncontrolled mating system and the rest 
Table 3. Production objectives and farmer traits preferences of indigenous chickens in the study area

\begin{tabular}{|c|c|c|c|c|c|c|c|c|c|c|c|c|c|}
\hline & \multicolumn{6}{|c|}{ Bako Tibe } & \multicolumn{6}{|c|}{ Dano } & \multirow{2}{*}{$\begin{array}{l}\text { Overall } \\
\text { index }(\mathrm{R})\end{array}$} \\
\hline Production objectives & R1 & $\mathrm{R} 2$ & R3 & \multicolumn{3}{|c|}{ Index } & $\mathrm{R} 1$ & $\mathrm{R} 2$ & R3 & \multicolumn{3}{|c|}{ Index } & \\
\hline Egg consumption & 10 & 42 & 6 & \multicolumn{3}{|c|}{$0.33(1)$} & 3 & 35 & 13 & \multicolumn{3}{|c|}{0.44} & $0.39(1)$ \\
\hline Egg sale & 12 & 11 & 33 & \multicolumn{3}{|c|}{$0.28(2)$} & 4 & 14 & 30 & \multicolumn{3}{|c|}{0.26} & $0.27(2)$ \\
\hline Meat sale & 0 & 1 & 8 & \multicolumn{3}{|c|}{$0.03(5)$} & 0 & 4 & 9 & \multicolumn{3}{|c|}{0.05} & $0.04(5)$ \\
\hline Meat consumption & 6 & 5 & 5 & \multicolumn{3}{|c|}{$0.09(4)$} & 2 & 1 & 4 & \multicolumn{3}{|c|}{0.03} & $0.06(4)$ \\
\hline Chick sale & 31 & 1 & 4 & \multicolumn{3}{|c|}{$0.25(3)$} & 50 & 2 & 3 & \multicolumn{3}{|c|}{0.20} & $0.23(3)$ \\
\hline Ceremonies / festivals & 1 & 0 & 4 & \multicolumn{3}{|c|}{$0.02(6)$} & 0 & 3 & 0 & \multicolumn{3}{|c|}{0.02} & $0.02(6)$ \\
\hline $\begin{array}{l}\text { Trait preferences for } \\
\text { selection of hens }\end{array}$ & $\mathrm{R} 1$ & R2 & R3 & R4 & R5 & Index & $\mathrm{R} 1$ & $\mathrm{R} 2$ & R3 & R4 & R5 & Index & \\
\hline Body size / weight & 12 & 4 & 15 & 17 & 8 & $0.20(2)$ & 30 & 4 & 5 & 8 & 12 & 0.25 & $0.23(2)$ \\
\hline Growth rate & 1 & 9 & 6 & 10 & 19 & $0.13(4)$ & 2 & 13 & 7 & 16 & 12 & 0.16 & $0.15(4)$ \\
\hline Feed requirements & 0 & 0 & 0 & 0 & 0 & 0.00 & 0 & 1 & 2 & 1 & 1 & 0.02 & $0.01(10)$ \\
\hline Body/feather color & 1 & 1 & 3 & 2 & 4 & $0.04(6)$ & 0 & 1 & 5 & 6 & 2 & 0.04 & $0.04(6)$ \\
\hline Leg length & 2 & 3 & 8 & 3 & 0 & $0.07(5)$ & 0 & 2 & 17 & 5 & 3 & 0.09 & $0.08(5)$ \\
\hline Comb shape & 0 & 0 & 0 & 0 & 0 & 0.00 & 0 & 0 & 1 & 1 & 3 & 0.01 & $0.01(10)$ \\
\hline Wing span & 0 & 0 & 1 & 3 & 1 & $0.01(10)$ & 0 & 0 & 1 & 1 & 0 & 0.01 & $0.01(10)$ \\
\hline Chick production rate & 0 & 3 & 0 & 2 & 1 & $0.02(9)$ & 0 & 0 & 1 & 1 & 0 & 0.01 & $0.02(9)$ \\
\hline Clutch length & 1 & 0 & 1 & 4 & 1 & $0.01(10)$ & 0 & 1 & 0 & 0 & 1 & 0.01 & $0.01(10)$ \\
\hline Egg size/weight & 2 & 1 & 2 & 1 & 5 & $0.04(6)$ & 0 & 0 & 0 & 0 & 0 & 0.00 & $0.02(8)$ \\
\hline Scavenging ability & 0 & 1 & 1 & 1 & 1 & $0.03(8)$ & 0 & 1 & 3 & 0 & 1 & 0.02 & $0.03(7)$ \\
\hline Brooding ability & 1 & 20 & 12 & 5 & 3 & $0.18(3)$ & 0 & 25 & 6 & 13 & 0 & 0.18 & $0.18(3)$ \\
\hline Egg productivity & 30 & 8 & 1 & 2 & 7 & $0.27(1)$ & 22 & 6 & 7 & 2 & 18 & 0.20 & $0.24(1)$ \\
\hline \multicolumn{14}{|c|}{ Traits preferences for selection of cocks } \\
\hline Body size / weight & 15 & 2 & 1 & 2 & 3 & $0.31(1)$ & 9 & 0 & 5 & 7 & 5 & 0.33 & $0.32(1)$ \\
\hline Growth rate & 2 & 6 & 6 & 2 & 1 & $0.19(2)$ & 0 & 1 & 5 & 1 & 0 & 0.09 & $0.14(4)$ \\
\hline Feed requirements & 0 & 0 & 0 & 0 & 0 & 0.00 & 0 & 0 & 0 & 1 & 0 & 0.01 & $0.005(7)$ \\
\hline Feather colour & 0 & 3 & 3 & 7 & 0 & $0.12(5)$ & 3 & 0 & 3 & 1 & 6 & 0.13 & $0.13(5)$ \\
\hline Leg length & 1 & 3 & 7 & 3 & 8 & $0.17(3)$ & 0 & 4 & 3 & 3 & 0 & 0.13 & $0.15(3)$ \\
\hline Comb shape & 1 & 6 & 3 & 4 & 2 & $0.16(4)$ & 4 & 11 & 0 & 3 & 5 & 0.31 & $0.24(2)$ \\
\hline Comb type & 0 & 0 & 0 & 0 & 3 & $0.01(8)$ & 0 & 0 & 0 & 0 & 0 & 0.00 & $0.005(7)$ \\
\hline Scavenging ability & 1 & 0 & 0 & 2 & 3 & $0.04(7)$ & 0 & 0 & 0 & 0 & 0 & 0.00 & $0.02(6)$ \\
\hline
\end{tabular}
R: Rank

Table 4. Selections of chicken for breeding and culling practices of farmers and sources of foundation stocks in the study area

\begin{tabular}{|c|c|c|c|c|}
\hline \multicolumn{2}{|l|}{ Parameter } & Bako Tibe $(\%)$ & Dano $(\%)$ & Overall $(\%)$ \\
\hline \multirow[t]{2}{*}{ Selection of chickens for breeding } & No & 16.67 & 8.47 & 12.57 \\
\hline & Yes & 83.33 & 91.53 & 87.43 \\
\hline \multirow{2}{*}{$\begin{array}{l}\text { Type of mating used for } \\
\text { Breeding }\end{array}$} & Controlled & 96.00 & 91.00 & 93.500 \\
\hline & Uncontrolled & 4.00 & 9.00 & 6.500 \\
\hline \multirow[t]{2}{*}{ Culling experience } & No & 41.70 & 54.20 & 47.95 \\
\hline & Yes & 58.30 & 45.80 & 52.05 \\
\hline \multicolumn{5}{|l|}{ Culling criteria } \\
\hline \multicolumn{2}{|l|}{ Old age } & - & 55.60 & 27.80 \\
\hline \multicolumn{2}{|l|}{ Poor egg production } & 60.00 & 33.30 & 46.65 \\
\hline \multicolumn{2}{|l|}{ Disease concerns (in flock or bird) } & 2.90 & - & 1.45 \\
\hline \multicolumn{2}{|l|}{ Old age and poor egg Production } & 31.40 & - & 15.20 \\
\hline \multicolumn{2}{|c|}{ Poor egg production and poor egg quality } & - & 7.40 & 3.70 \\
\hline \multicolumn{2}{|c|}{ Old age, poor egg production, and poor egg quality } & 5.70 & - & 2.85 \\
\hline \multicolumn{2}{|c|}{ Old age, poor egg production, poor egg quality, and disease concerns } & - & 3.70 & 1.85 \\
\hline \multirow[t]{3}{*}{ Source of foundation stocks } & Purchased & 65.00 & 67.80 & 66.40 \\
\hline & Inherited & 33.30 & 32.20 & 32.75 \\
\hline & Gift & 1.70 & - & 0.85 \\
\hline
\end{tabular}

(\%): Percent, -: not observed 
$6.50 \%$ used a controlled mating system. This may be due to the majority of the farmer's practices scavenging chicken production systems. The current result was higher than the report of Alemayehu and Misba (2018), who report $81.90 \%$ of the farmers used an uncontrolled mating system in the Lume district.

\section{The Culling experiences and sources of foundation stocks}

Culling practices and source of foundation stocks were presented in Table 4 . About 52.05\% of respondents used different criteria to cull their chickens in the study area. Poor egg production (46.65\%) and old age (27.80\%) were the major criteria in which the farmers were used to cull their chickens and it is an important breeding practice to remove un-productive flocks in districts. The present study corresponded with the finding of Muchadeyi et al. (2009) and Zemelak et al.(2016) who reported poor productions, diseases, old age are some of the major causes of culling in different agro-climatic zone of Zimbabwe and Ethiopia, respectively. However, the finding of Alemayehu and Misba(2018) who reported 98.90\% of respondent in Lume district were practiced culling of chickens which were higher than the current result. The current result also indicates that the major source of foundation stock was purchasing chicken from the local market followed by inherited in the study area and it was in line with the report of Tadelle et al. (2003), who reported, purchase as the main source of birds for the foundation stock in Ethiopia.

\section{Conclusions}

From the result of the study, it is possible to conclude that, the indigenous chickens provide high-quality protein to family nutrition and generate income for smallholder households even though its production and reproduction performances were low. The majority of the farmers practiced selection of hens and cocks for breeding purposes based on productivity traits of the chickens which show egg and meat production was the major aims of the farmer to raises chickens in the study area. Identification and understanding of farmers breeding objectives and farmers' traits of chickens might be used in future research direction and the intervention to increase the genetic potential of local chickens through the selection and crossbreeding with tropically adapted exotic breeds which give more production in semi scavenging chicken production system to satisfy the need of community focusing on improvement of those traits.

\section{Acknowledgments}

The authors would like to thank International Livestock Research, African Chicken Genetic Gain (ACGG) project for financial support during the study. Bako Agricultural Research Center is appreciated for all the facility and other technical support; and also the respondents who participated in the study were duly acknowledged for their willingness to provide valuable information.

\section{Conflict of Interests}

The authors declared no conflict of interest.

\section{References}

1) Addisu H, Hailu M, Zewdu $W, 2013$. Indigenous chicken production system and breeding practice in North Wollo, Amhara region, Ethiopia. Scholarly Journal of Agricultural Science 3(10):433-444.

2) Adem A, Teshome G,2016. Indigenous chicken production system and their productive performance in Yeki Woreda, Southwestern Ethiopia. Agricultural and Biological Journal of Northern America 7 (5):266-274.

3) Alem T,2014. Production and reproduction performance of rural poultry in low altitude and mid-altitude agroecological zones of Central Tigray, Northern Ethiopia. British Journal of Poultry Sciences 3: 6-14.

4) Alemayehu G, Misba A,2018. Farmers' Breeding Practice \& Traits of Economic Importance for Indigenous Chicken in Lume District, Oromia Regional State, Ethiopia. Global Journal of Science Frontier Research: D Agriculture and Veterinary Volume 18 Issue 8 Version 1.0 Double-Blind Peer Reviewed International Research Journal Publisher: Global Journals Inc. (USA).

5) Boere A, Vernooij A, Hilde DH, Mebratu L, Dawit K,2015. Investment opportunities in the Ethiopian Poultry sub-sector. Business Opportunities Report Poultry \#3 in the series written for the "Ethiopian Netherlands business event, 5-6 November 2015, Rijswijk, The Netherlands."

6) Central Statistical Agency [Ethiopia] and ICF International , 2012. Ethiopia Demographic and Health Survey 2011. Addis Ababa, Ethiopia and Calverton, Maryland, USA: Central Statistical Agency and ICF International. http://www.sciepub.com/reference/109537

7) CSA (Central Statistical Agency) (2016/2017). Livestock and Livestock Characteristics (Private Peasant Holdings) Agricultural Sample Survey Volume II. Federal Democratic Republic of Ethiopia, Addis Ababa. Agri-cultural sample survey. Volume II, Report on livestock and livestock characteristics ( private peasant 
holdings) in Search Works catalog https://searchworks.stanford.edu/view/6509594

8) Chencha C, Hailemichael N, 2016. Performances, breeding practices and trait preferences of local chicken ecotypes in southern zone of Tigray, northern Ethiopia. Asian Journal of Poultry Science, 10:158-164.

9) Daikwo I, Okpe A, Ocheja J, 2011. Phenotypic characterization of local chickens in Dekina. International Journal of Poultry Science 10(6):444-447.

10) Dereje B, Kefelegn K, 2016. On Farm Phenotypic Characterization of Indigenous Cattle in Bako Tibe and Gobu Sayo Districts of Oromia Region, Ethiopia. Journal of Biology, Agriculture and Healthcare, 6(19): 94-103.

11) Dereje B, Habtamu A, Fayera B,2015. Characterization of Indigenous Chicken Production and Utilization in Western Oromia, Ethiopia. Brit-ish Journal of Poultry Sciences 4 (3): 53-59.

12) Ekka R., Behura L. Samal N.C., Nayak G.D., Pati P.K. and Mishra P.K. 2016. Growth performance and linear body measurements of Hansli, CSML and HanslixCSML cross under intensive system of rearing. Journal of Livestock Science 7: 114-121

13) Emebet M, Hareppal S, Johansson A, Tesfaye S, Zemelak S,2013. Characteristics of Indigenous Chicken Production System in South-west and South Part of Ethiopia. British Journal of Poultry Sciences 2 (3): 2532.

14) Eskindir A, Kefelegn K, Tadelle D, Banerjee A. K, 2013. Phenotypic Characterization of Indigenous Chicken Population in Ethiopia. International Journal of Interdisciplinary and Multidisciplinary Studies, Vol 1,No.1,24-32. httt://www.ijims.com.

15) FAO,2014. Decision tools for family poultry development. FAO Animal Production and Health Guidelines No. 16. Rome, Italy. Decision tools for family poultry development.

16) FAO,2019. Poultry Sector Ethiopia. FAO Animal Production and Health Livestock Country Reviews. No. 11. Rome. Livestock Country Review - Poultry Sector Ethiopia.

17) FAOSTAT,2016. Food and Agricultural Organization of the United Nations, statistical division. http://faostat3.fao.org /browser/Q/QA/E. Last accessed on 02 August 2018.

18) FAS (Foreign Agricultural Service), 2017. Ethiopia's Demand for Chicken Meat is expected to grow. Gain report number ET1712. June 6/7/2017, Addis Ababa, Ethiopia. https://www.fas.usda.gov/data/ethiopia

19) Fisseha M,2014. Chicken Production and Marketing Systems in Enkulal Watershed, Dera District, Amhara Region, Ethiopia. World's Veterinary Journal 4(4):35-41.

20) Fisseha M, Azage T, Tadelle D, 2010. Indigenous chicken production and marketing systems in Ethiopia: Characteristics and opportunities for market-oriented development. IPMS (Improving Productivity and Market Success) of Ethiopian Farmers Project Working Paper 24. Nairobi, Kenya, ILRI.

21) Getachew B, Kefelegn K, Negassi A, 2015. On-farm Phenotypic Characterization of Indigenous Chicken and their Production System in Bench Maji Zone, South Western Ethiopia.Sci.Technol.Arts.Res.J.,4(1):6873.DoI:http://dx.doi.org/10.4314/star.v4i1.10.

22) Habte T, Amare A, Bettridge J, Collins M, Christley R, Wigley P,2017. Guide to chicken health and management in Ethiopia. ILRI Manual 25.Nairobi, Kenya: International Livestock Research Institute (ILRI). https://www.researchgate.net

23) Hailemichael N, Kefelegn K, Negassi A,2015. Survey on Indigenous Chicken Production and Utilization Systems in Southern Zone of Tigray, Northern Ethiopia. Food Science and Quality Management 45 (9199).

24) Horst $P, 1989$. Native fowl as reservoir for genomes and major genes with direct and indirect effects on the adaptability and their potential for tropically oriented breeding plans, Archiv für Geflügelkunde, 53(3), 93101.

25) Hunde W, Singh H, Mulisa M ,2016. Studies on Management Practices and Constraints of Back Yard Chicken Production in Selected Rural Areas of Bishoftu. Journal of Veterinary Science and Technolgy S12: S12003. DOI: $10.4172 / 2157-7579.1000 S 12-003$

26) Janvier M, Muasya TK, Mbuza F, Habimana R, Kahi AK,2017. Characterization of indigenous chicken production systems in Rwanda. Journal of Poultry Science 96 (12):1-8.

27) Kosgey IS, 2004. Breeding Objectives and Breeding Strategies for Small Ruminants in the Tropics. Ph.D. Thesis at Wageningen University, Wageningen, Netherlands.

28) Muchadeyi, F.C., Wollny, C.B.A., Eding, H., Weigend, S., Simianer, H., 2009. Choice of breeding stock, preference of production traits and culling criteria of village chickens among Zimbabwe agroecological zones. Tropical Animal Health and Production, 41, 403-412.

29) Nigussie D, Liesbeth H, Tadelle D, Johan AM, 2010. Production Objectives and Trait Preferences of Village Poultry Producers of Ethiopia: Implications for Designing Breeding Schemes Utilizing Indigenous Chicken 
Genetic Resources. Tropical Animal Health and Production (42):1519 -1529. DOI: 10.1007/s11250-0109602-6 PubMed

30) SPSS, 2011. Statistical Package for Social Science, SPSS 20 for Windows. SPSS Inc. Chicago, Illinois.

31) Tadelle D, Million T, Alemu Y, Peters KJ, 2003. Village chicken production system in Ethiopia. Livestock Research \& Rural Development 15(1): 4-8.

32) Wondu M, Mehiret M, Berhan T,2013. Characterization of Urban Poultry Production System in Northern Gondar, Amhara Regional State, Ethiopia. Agriculture and Biology Journal of North America 4(3): 192198.

33) Wong JT, de Bruyn J, Bagnol B, Grieve H, Li M, Pym R, Alders RG, 2017. Small-scale poultry and food security in resource-poor settings: A review. Global Food Security, 15, pp.43-52.

34) Yadeta N, Jabesa A, Mengistu A,2019. Village Chicken Production Performances and Producers Trait Preference in Buno Bedele and Ilu Ababor Zone South-Western Ethiopia. British Journal of Poultry Sciences 8 (2): 34-43, 2019.

35) Zemelak G, Luizinho C, Cassio W,Gudrun A. B, 2016.Characterization of village chicken production systems and challenges across agro-climatic zones in Ethiopia. International Journal of Livestock Production 7(11): 94-105. DOI: 10.5897/IJLP2016.0320. 